\title{
Ethnicities and Conflict: A Survey Experiment on the Effect of Narrative Framing on Perceptions in Jos, Nigeria
}

\author{
LAURA THAUT VINSON (1) \& PETER RUDLOFF (1)** \\ *Lewis \& Clark College, USA, **Oklahoma State University, USA
}

\begin{abstract}
Where ethnic violence divides groups by both religious and tribal affiliation, how does the 'ethnic' characterization of conflict affect perceptions of the crises? From a survey experiment in Jos, Nigeria, we find that priming respondents with religious versus tribal conflict frames leads respondents to differently interpret the causes of violence, with religious issues viewed as the most salient cause of violence and religion the most important solution. The findings emphasize that where more than one ethnic identity is salient to conflict, the causes of violence take on different meaning depending on how individuals interpret the ethnic dimension of local violence.
\end{abstract}

\section{Introduction}

In Jos, Nigeria, grassroots, religious, and international (or internationally funded) organizations engage in programmes to restore communal trust between the ethnic groups affected by intense bouts of communal violence recurring since 2001 . Yet, peace meetings between local stakeholders, traditional leaders, religious leaders, and political representatives are often characterized by disagreements regarding the fundamental question of what type of ethnic conflict Jos actually represents. In one peace meeting of prominent local actors and officials observed in 2011, the goal of the event-to come to a consensus on peacebuilding strategies - made little headway on the actual topic of peacebuilding. Participants instead argued about whether the conflict was really religious, tribal, ${ }^{1}$ or rooted in nonideational factors such as political or economic disputes, or some combination of these (Vinson, 2017).

This anecdote illustrates the importance of local perceptions of the ethnic dimensions of identity-based conflict, as well as critical questions of empirical significance for ethnic conflict studies. Regarding the latter, the designation 'ethnic' is commonly used as an umbrella category for various ethnic identities-e.g. language, caste, race, tribe, and religion (Chandra, 2012, p. 9; Chandra \& Wilkinson, 2008, p. 519; Horowitz, 1985, p. 53). However, treating cases of ethnic conflict that might have different identity dimensions

Correspondence Address: Laura Thaut Vinson, Department of International Affairs, Lewis \& Clark College, 615 S. Palatine Hill Road, Portland, OR 97219, USA. Email: 1vinson@1clark.edu 


\section{L. Thaut Vinson and P. Rudloff}

as merely cases of some larger 'type,' or as synonymous with tribal or ethno-linguistic conflict, overlooks potential empirical differences in identity and conflict mobilization (e.g. Gurses, 2015; Vinson, 2020). Further, many communities affected by ethnic conflict, from Myanmar and India to Nigeria and the Central African Republic, experience conflict with overlapping ethno-tribal and ethno-religious dimensions. These conflicts are some of the most intractable in the world, defying attempts at peacebuilding by local and global leaders. Despite considerable research on the causes of ethnic violence (e.g. Horowitz, 1985; Laitin, 1986; Varshney, 2001), gaps remain in our understanding of the role of identity in shaping inter-group attitudes and incentives for violence (see Gohdes, 2017; Gurr, 2017; Hale, 2017), particularly when ethnic conflict is characterized by overlapping cleavages such as religion and tribe. In communities where communal violence divides groups by more than one overlapping ethnic identity, does the particular 'ethnic' characterization of conflict affect how community members perceive the root causes of the crises and assign blame?

This unanswered question has important implications. As noted above, ethnic groups may be characterized by various identity cleavages-e.g. race, religion, tribe/kinship, caste, and language - with divergent symbolic dimensions that are not captured by the prominent models or tools of analysis. This clouds our understanding of how individual perceptions of ethnic identity shape inter-group attitudes and mobilization. Noting this shortcoming, McCauley (2017, p. 16) observes, 'Models that treat groups simply as groups explain a spectrum of conflicts with concise logic, yet they fall short in recognizing some of the systematic differences that arise across identity contexts.' Conflating ethnic dimensions risks overlooking how these different identities may distinctly shape individual perceptions of and attitudes towards violence and peace, as well as the causes of violence and its perpetrators (Dowd, 2014, p. 165; Gurses, 2015, 2018).

We test arguments that different ethnic identities can distinctly shape perceptions of conflict and inter-group attitudes by exploring group blame and issue blame in the context of communal violence ${ }^{2}$ in Jos, Nigeria, where religious and tribal identities overlap. Through the use of a survey experiment across the greater Jos metropolis, we examine the effect of different identity conflict frames on how individuals view the causes of communal violence in Jos, the driving issues, and the implications in terms of their views of conflict resolution and solutions. Testing a series of hypotheses, we ultimately find that priming the conflict through an identity frame-tribal and/or religious - shapes individuals' views of the conflict issue and solutions, even if they are more circumspect about who is to blame for the violence. Overall, the findings support our argument that ethnic conflict should not be reduced simply to political or material explanations, as perceptions of conflict, particularly in contexts of different types of ethnic identities, can distinctly shape views of local communal violence.

\section{Literature Review}

Various factors exacerbate ethnic cleavages and result in inter-group violence, including the economic disparities between ethnic communities (Fjelde \& Østby, 2014; Gurr, 2000; Pierskalla \& Sacks, 2017; Stewart, 2008); self-interested political entrepreneurs who mobilize ethnic identities—-the instrumentalist argument—particularly around election periods (Brass, 1997; Gagnon, 1994; Posner, 2004); and ethnic favouritism or weak mechanisms of inclusion at the national level (Miguel, 2004). In contrast, ideational or 
constructivist theories emphasize that work focusing on material interests and political entrepreneurs is incomplete if it does not consider how ascriptive or cultural identities and their symbolic markers shape and constrain mobilization (Brubaker \& Laitin, 1998; Horowitz, 2001; Kaufman, 2001). The middle ground in this debate recognizes that identity can be strategically mobilized, but also rooted in salient local identity narratives (e.g. Horowitz, 2001, p. 47; Laitin, 1986; Ross, 2009; Varshney, 2003). We too take seriously the significance of cultural identities in (differently) shaping inter-group attitudes and conflict, as opposed to analyses that treat identity as merely subject to the mobilization whims of political entrepreneurs motivated purely by economic and political ambition. While material and political interests and incentives can also be fundamental drivers of conflict, this project similarly emphasizes that how grievances or conflict issues are associated with cultural identity matters. We ultimately believe that both material and ideational causes matter, even if the focus of this paper is on the different dimensions of identity. Better understanding the construction of these identities-how identities are mapped onto and shape perceptions of conflict causes, issues, and solutions-in local contexts of ethnic violence, then, can tell us more about the capacity of these identities to serve as salient sources of not only conflict mobilization but also peacebuilding (see also Gurses, 2015, 2018).

Recent scholarship focuses on the impact of identity on inter-group attitudes in the context of ethnic conflict, cleavages, or political violence. Critiques of macro-level aggregate studies of ethnic conflict echo Green and Seher's (2003, p. 524) call for exploring 'micro-level processes' through tools of social psychological analysis (e.g. CanettiNisim et al., 2008; Flesken, 2014; Gohdes, 2017; Kasara, 2013, p. 934; McDoom, 2012; Smirnova \& Lliev, 2017; see Canetti et al., 2019) to better understand how individuals perceive and construct their identity vis-à-vis others (Gohdes, 2017; McDoom, 2012, p. 121). Aggregate studies typically cannot capture how the different dimensions of identity, the possible sub-group divisions in identity construction, or differences in individual processes of identification (e.g. within categories of Muslim or Christian) influence conflict (see McDoom, 2012). Further, coding conflict events as a 'type' of ethnic conflict based on broad group identities tells us little about the actual role of ethnic identity or its salience to the conflict (see Canetti et al., 2019, p. 738; Gohdes, 2017, p. 30). More broadly, we are unable to determine from macro-level data how or under what conditions aspects of ethnic identity matter for ethnic conflict processes (e.g. Smirnova \& Lliev, 2017; see also Selvanathan \& Leidner, 2020).

These and other critiques have thus given rise to research in the micro-level vein that explores how identity affects intergroup attitudes and interacts with other factors to shape in-group identification and out-group hostility, prejudice, or policy discrimination in ethnic conflict or divided societies (e.g. Aroopala, 2012; Canetti et al., 2019; CanettiNisim et al., 2008; Flesken, 2014; Kasara, 2013; McDoom, 2012; Selvanathan \& Leidner, 2020; Smirnova \& Lliev, 2017). For example, Kalin and Siddiqui (2020) find that intolerant and discriminatory attitudes toward the Ahmadi religious minority in Pakistan are mediated by how closely the minority is identified with the nation (see also Charnysh et al., 2015). Flesken (2014) examines how changing political events in Bolivia affected group cohesion and self-categorization in relationship to indigenous identity and race.

Understanding how identity and conflict interact is also an important area of study in the peacebuilding literature. Research explores how to reduce inter-group hostility based around identity cleavages through dialogue or 'contact' interventions. Stemming from 
Allport's (1954) work on contact theory, studies using surveys and experiments generally confirm the positive effects of intergroup contact on individual attitudes, although such studies are generally not conducted in a context of ongoing ethnic conflict (e.g. see discussion in Pettigrew \& Tropp, 2006). Intergroup dialogue or contact can reduce discrimination or stereotypes and generally promote more positive intergroup perceptions (e.g. Dessel \& Rogge, 2008; Scacco \& Warren, 2018; Tusicisny, 2017). Hence, better understanding how ethnic identity distinctly shapes inter-group attitudes serves the goals of conflict resolution in divided societies.

Our study also emphasizes micro-level analysis of ethnic identity and conflict, however, we focus on an understudied area-inter-group attitudes where there are multiple salient overlapping ethnic identities that serve as meaningful conflict cleavages, as is common to African and South Asian conflict cases (see Basedau et al., 2011). For example, in Myanmar, persecution of non-indigenous ethnic Rohingya (Muslim) and indigenous ethnic Burmese (Hindu) takes on more than one ethnic dimension. Similarly, Sri Lanka experienced decades of violence between the majority Sinhalese Buddhist population and the Tamil Hindu minority. Stewart (2008, p. 12) notes the overlap of ethnic and religious identities in Poso, Indonesia (affected by communal violence in the early 2000s) and the Balkans, as well as the overlap of caste and ethnicity in Nepal. Similarly, ethnic conflict in north-central Nigeria also involves overlapping ethno-tribal and ethno-religious cleavages.

As Kolås (2017) observes in northeast India, and similar to our own anecdotal fieldwork observations, the 'ethnic conflict' label is itself a point of contestation among local communities. If individuals possess multiple identities that can become salient when activated by political or socio-economic changes (Brubaker, 2015; Chandra, 2012, p. 3; Wimmer, 2008), what is the significance of these different identity associations when more than one is 'activated' or a part of local conflict frames? For example, Canetti et al. (2019, p. 738) find that divergent conflict frames-nationalist vs. religious-in the context of the Israeli-Palestinian conflict are not merely semantics to local actors; they can 'also entail downstream effects on behavior, leading to different prognostic assessments about the conflict' and shape the willingness of individuals to resolve the conflict. Rather than impose an identity or non-identity label on a conflict, we ask how individuals affected by conflict interpret salient conflict frames.

To assess whether or how individuals associate salient ethnic identities in Jos with local communal violence, we designed a survey experiment to study how the ethnic priming of communal conflict as religious and/or tribal affects individuals' perceptions of the conflict causes and who is to blame. This approach will tell us not only whether viewing local conflict and violence through an ethnic lens meaningfully shapes individuals' views of the conflict (as opposed to viewing it through a non-identity lens), but also whether there are meaningful differences in individuals' views of the conflict if they are primed to view it through a tribal or religious lens. As we find, the relationship is by no means straightforward, with significant variation between the identity issues (tribal vs. religious) seen as underlying conflict and whether tribal or religious groups are to blame for conflict.

\section{Case Study Motivation and Context}

The north-central or Middle Belt region of Nigeria has been particularly prone to communal ethnic violence since the mid-1980s. Plateau state, of which Jos is the capital, was one 
of the most peaceful states in the Middle Belt, avoiding the conflagrations occurring in neighbouring states (Best, 2008, p. 10). However, since 2001, Jos has become one of the cities prone to recurring communal violence, including particularly deadly bouts of ethnic riots in 2001, 2004, 2008 and 2010 (Best, 2008; Higazi, 2011; Krause, 2019; Madueke, 2018; Ostien, 2009; Vinson, 2017), along with more recent farmer-herder clashes with ethnic dimensions (International Crisis Group, 2018). Paden (2012, p. 79), discussing the upsurge in ethno-religious violence in Nigeria notes, 'Without question, Plateau State has had the largest number of violent deaths from conflict of any state in Nigeria: many thousands have died since 1999.' Four days of violence in 2010 sparked by a local dispute, for example, killed at least 1,000 Jos residents and displaced an estimated 10,000-18,000 (Human Rights Watch, 2011; Krause, 2011; Kwaja, 2011). A number of smaller, less deadly incidents have contributed to the ongoing local concern that violence could, given the right kind of spark, engulf parts of the city once again. Hence, Jos is an important context for this study, since it is in the center of the country, where the plate tectonics of ethnicity and religion interact, and where the symbolism of Muslim-Christian cooperation or conflict have enormous implications for the whole country' (Paden, 2012, p. 95).

Considering the array of causal factors cited, it is no surprise that Falola (1998, p. 12ff) concludes, 'it is clear that a monocausal explanation is grossly inadequate' (see also Paden, 2012, p. 97ff). Rather, scholars offer important insight into factors at different levels contributing to or incentivizing violent mobilization. On the political front, the increase in communal ethnic violence, particularly since Nigeria's transition to civilian rule in 1999, can be attributed to a range of national- and local-level factors. Scholars emphasize, for example, weak government institutions and weak or failed security provisions (Kwaja, 2011; Mayowa, 2001); the manipulation of religion in the struggle for political power at the national and local levels (Falola, 1998, pp. 2-5; Kwaja, 2011); the lack of power-sharing or political representation in local government councils (Bunte \& Vinson, 2016; Vinson, 2017); political and economic inequalities or exclusion in local representation, particularly the manipulation of indigeneity politics for local political gain (Higazi, 2011, p. 7; Kwaja, 2011; Ostien, 2009); political competition or patronage politics (Best, 2008, p. 21; Higazi, 2011 , p. 9); the presence or absence of local leaders and social networks to constrain violent mobilization (Krause, 2017; Scacco, 2010); and religious revivalism within and competition between both Islam and Christianity (Paden, 2012, pp. 78-79). The research emphasizes, therefore, that political actors have clearly exacerbated the conflict and competition for power, such as political competition over control of the Jos North local government area and over influential state and local government positions or appointments. Given not only the political but also economic implications for the conflict communities, it is not surprising that political events have become a locus of conflict that has at times sparked communal violence or furthered tensions.

As noted in the introduction, however, the role of ethno-tribal and ethno-religious identity-the way in which it is mapped onto and mobilized in local communal violence-is a constant subject of debate in Jos (and elsewhere in the Middle Belt) due to the overlapping dimensions of tribal and religious identities. The conflict in Jos could clearly be read as an ethno-tribal conflict pitting indigenous Berom, Afizere, and Anaguta against the non-indigenous Hausa-Fulani (Madueke, 2018; Segun \& Jegede, 2013). On the other hand, religious divisions are also highly salient or a useful cleavage, with indigenous and non-indigenous designations breaking down neatly along Christian 
versus Muslim lines (Krause, 2011, 2017, p. 270; Vinson, 2020). Madueke (2018, p. 449) notes that the city's segregation as a product of communal violence can be described as 'either religious or ethno-linguistic or both,' and that '[i]n Jos city centre, segregation is mainly religious but also ethnolinguistic in some cases, since religious and ethno-linguistic boundaries tend to overlap' (see similar discussion in Best, 2008; Higazi, 2011; Krause, 2017; Madueke \& Vermeulen, 2018; Osaretin \& Akov, 2013, p. 351; Paden, 2012, p. 76; Segun \& Jegede, 2013). Shedrack Gaya Best (2008, p. 21), local scholar and expert, also observes that both the settler vs. indigenous and Muslim vs. Christian associations are similarly useful to 'pursue certain agendas and interests as well as [to] exclude and discriminate against others.' This leads Krause (2011, np) to conclude that while the dispute over indigene versus settler rights will need to be effectively addressed in order to achieve a lasting peace, 'religious leaders will have to take responsibility for deconstructing the perceptions of existential threat to religious identity that have become entrenched in many people's daily lives.' Due to these dynamics, Jos represents a case in which overlapping ethnic cleavages are highly salient to the communal violence.

\section{Theory and Hypotheses}

Given the salience of these identities, do individuals in Jos interpret violence differently depending on the ethnic identity perceived as central to the conflict? Individuals may simply find it cognitively straightforward to blame the group associated with the reported identity of the actors involved in communal violence, believing that, with the increased saliency of ethnic cleavages in Nigerian politics, appeals to group identity powerfully mobilize actors. On the other hand, anecdotal evidence from interviews and peace meetings during previous fieldwork suggests that Jos residents may have a more complex view of conflict actors and issues. They may be resistant to label violence in Jos and the region as fundamentally a battle between Muslims and Christians writ large, but may nonetheless perceive religious issues or offences as central to mobilization. This may particularly be the case since seemingly minor or symbolic religious offenses have become common instigators of violence in Jos and the Middle Belt (Human Rights Watch, 2001, p. 7; Krause, 2011; Vinson, 2020). Similarly, based on the previous discussion of the ethno-tribal dimensions of the Jos crisis, it is possible individuals perceive ethnotribal violence as rooted in failures to adequately resolve the indigeneity issue, rather than a fundamental group incompatibility. Even if the ethnic cleavages (tribal and religious) in a community neatly overlap, perceptions of the groups or issues responsible for violence may vary depending on the inferred identity dimension, since the symbolism and ideas associated with salient ethnic categories may differ.

Given the recognition of ethnic identity as a basis for in-group and out-group threat or prejudice (e.g. Canetti-Nisim et al., 2008; McDoom, 2012; Smirnova \& Lliev, 2017), we expect that individual perceptions of who is to blame for conflict will follow directly from the inferred source of conflict. Like much previous work that treats ethnicity as an umbrella category inclusive of various descent based attributes, the first hypothesis aggregates identity into a single 'ethnic' category:

Hypothesis 1a (Non-identity Group Blame): Subjects will be more likely to identify an identity group—religious or tribal—as responsible for conflict when prompted 
with information indicating identity-based violence than when no identity dimension is noted (i.e. 'communal conflict').

Second, we agree with recent critiques of the ethnic politics literature that aggregating identity dimensions obfuscates important differences that may exist between identities and conflict perceptions (e.g. Canetti et al., 2019; Gohdes, 2017; McCauley, 2017). If individual perceptions of conflict vary as we expect, the association of religion with violence should tap into distinct attitudes that place conflict responsibility on religious groups. Conversely, individuals should be more likely to associate conflict with tribal groups when presented with information that violence erupted along tribal lines. This leads to two additional hypotheses:

Hypothesis 1b (Religious Group Blame): Subjects will be more likely to identify religious groups as responsible for conflict when prompted with information indicating religious violence.

Hypothesis 1c (Tribal Group Blame): Subjects will be more likely to identify tribal groups as responsible for conflict when prompted with information indicating tribal violence.

Alternatively, we believe that subtleties may exist among individuals when reflecting on the causes of violence, particularly, whether groups or underlying issues are to blame for communal conflict. Blame follows the typical in-group versus out-group psychological logic (see Brewer, 1999; Tajfel \& Turner, 2004), whereby individuals assess external groups' responsibility for conflict differently from their own. Individuals may focus on and distinguish between what issues the groups are disputing, rather than blaming group members. For example, if the issue is that tribal leaders are disputing a communal resource, then negotiations can focus on an equitable division of the resource, and then enforcement of this agreement within their group. We therefore expect that prompting individuals with information that a conflict is both tribal and religious will lead individuals to identify tribal or religious issues as the source of conflict:

Hypothesis 2a (Non-identity Issue Cause): Subjects will be more likely to identify an identity issue - religious or tribal - at the root of violence when prompted with information indicating identity-based violence ('tribal or religious') than when no identity dimension ('communal') is noted.

Similar to Hypotheses $1 \mathrm{~b}$ and $1 \mathrm{c}$, however, we argue that significant differences may exist along distinct dimensions of ethnicity, with information of tribal conflict leading to perceptions of tribal issues as the cause, and information of religious conflict leading to perception of religious issues as the cause:

Hypothesis 2b (Religious Issue Cause): Subjects will be more likely to identify religious issues as the root of conflict when prompted with information indicating religious violence. 
Hypothesis 2c (Tribal Issue Cause): Subjects will be more likely to identify tribal issues as the root of conflict when prompted with information indicating tribal violence.

Finally, it is possible that certain identity dimensions, such as religious identity, may be considered more salient than other ethnic dimensions, even when both serve as a potential source of ethnic conflict (see Hasenclever \& Rittberger, 2000). With the increasing role of Christianity and Islam in national politics since the 1970s, the radicalization of Islam, the emergence of Boko Haram as a major security threat in the far north (especially since 2011), and the widespread incidence of communal violence in north-central Nigeria spanning various tribal divisions, individuals may be more likely to view the main actors and underlying causes through a religion-coloured lens. With the increasing influence since the 1970s of religious umbrella bodies like the Christian Association of Nigeria and Jamatu Nasri Islam-who not only advocate on behalf of their group interests at the highest political levels but also often interpret inter-group violence through a religious lens (see Campbell \& Page, 2018; Vinson, 2017)—religion is an important identity conflict frame in Nigeria.

It is not entirely clear, however, that individuals place the primary blame for local conflict on religious differences. As observed at peace meetings and other occasions during fieldwork in 2011 and 2016, individuals also cite a host of political, economic, and nonidentity issues as central to the violence in Jos. Nonetheless, the broader sacralization of conflict may shape individual perceptions of the violence despite the salient ethno-tribal cleavages:

Hypothesis 3a (Blame): Compared to tribal identity, subjects will be more likely to identify religious groups as responsible for conflict when prompted with information indicating no explicit identity dimension to local violence (i.e. 'communal').

Hypotheses 3b (Cause): A higher proportion of subjects will identify religion as the root of violence even when prompted with information indicating tribal violence than they will tribe as the root of violence when prompted with information indicating religious violence.

\section{Methods}

\section{Geographic Sampling Method}

In the ethnic politics literature, lab or field-based survey experiments are a common approach to gauge individuals' perceptions or attitudes toward an outgroup following a relevant intervention (e.g. Samii, 2013; Scacco \& Warren, 2018; Svensson \& Brouneus, 2013). We believe that a randomized survey experiment is a powerful method for testing perceptions of different ethnic dimensions and that Jos provides an ideal context for studying these ethnic differences. Our empirical analysis relies on individual survey data from a total of 1,769 surveys collected during the summer of 2016 in Jos, Nigeria. ${ }^{3}$ Randomly sampling individuals is impossible in Jos as there is no list of the population. It is common to use sampling techniques based on 'walking' various geographic areas from starting points such as polling stations (e.g. Finkel et al., 2012). However, such 
sampling techniques are less than ideal, as they rely on polling stations being spatially correlated with population density, and we are wary of this assumption. ${ }^{4}$

We used a geographic sampling method by overlaying Jos and the immediate surrounding area with a grid and then randomly selected cells within this grid to conduct surveys (QGIS Development Team, 2016). We attempted to control for population density by counting the number of distinct building constructions within each cell using satellite imagery (Google, 2016) and randomly sampling one building for each five buildings in selected cells. Selected buildings represented a location a survey experiment would be conducted (cells without any buildings were discarded). Research assistants from the University of Jos were trained and then sent to each of these selected locations via GPS device to conduct a survey with a tablet device using the Questionnaire Development System (QDS) software (Nova Research Company, 2016), allowing the survey to be conducted via audio for illiterate participants. An adult from each location was randomly selected and offered the opportunity to take the survey.

A number of precautions were taken to ensure the safety of participants and research assistants. First, research assistant training focused on safety, and they were placed in Christian or Muslim pairs so they could be sent to Christian and Muslim neighbourhoods, respectively. This was important, as strangers, particularly strangers from another competing tribal/religious group, might be seen with suspicion and challenged. Second, research assistants were instructed to abandon any survey where they perceived any threat to themselves and to report any instances so these areas could be avoided in the future. Third, research assistants were given letters from a reputable local educational institution (the University of Jos) to establish their credibility, and were recruited from the university itself. Finally, all research assistants were strictly instructed on the importance of debriefing participants to avoid the spread of conflict rumours. ${ }^{5}$

\section{The Survey Experiment}

The survey experiment included an intervention of a carefully constructed hypothetical news article constructed by the researchers. ${ }^{6}$ One of four possible interventions was randomly assigned to a participant. Figure 1 in the Appendix presents the four hypothetical news articles that served as randomized treatments. Article $A$ serves as a control from which the effects of the other treatments can be compared. The baseline article notes that 'communal' conflict has resulted in dozens of deaths, that the event was nearby, and calls back to recent episodes of violence. Each of the other articles retains the same underlying facts, but presents the incidents as either religious (Article B), tribal (Article $C$ ), or both religious and tribal (Article $D$ ). The articles make no reference to causes of the violence. Thus, the participant may be presented with a conflict event framed along one or both of the two dimensions of ethnic identity salient in Jos, and their perception of conflict and the various 'actors' noted at the end of the article can be examined. Each article is related to a pair of our competing hypotheses.

To ensure the treatment is strong enough to elicit the attention of participants, we note that 'no fewer than 50 persons were killed.' In the context of Jos and the broader northern region of Nigeria, this level of violence signifies a fairly major incident of communal violence. According to data collected by Vinson (2020, p. 26) on ethno-religious and ethnotribal communal violence between 1979 and 2011 in northern Nigeria, ethnic communal violence most commonly involves 1-10 deaths (approximately $68 \%$ of all lethal incidents), 

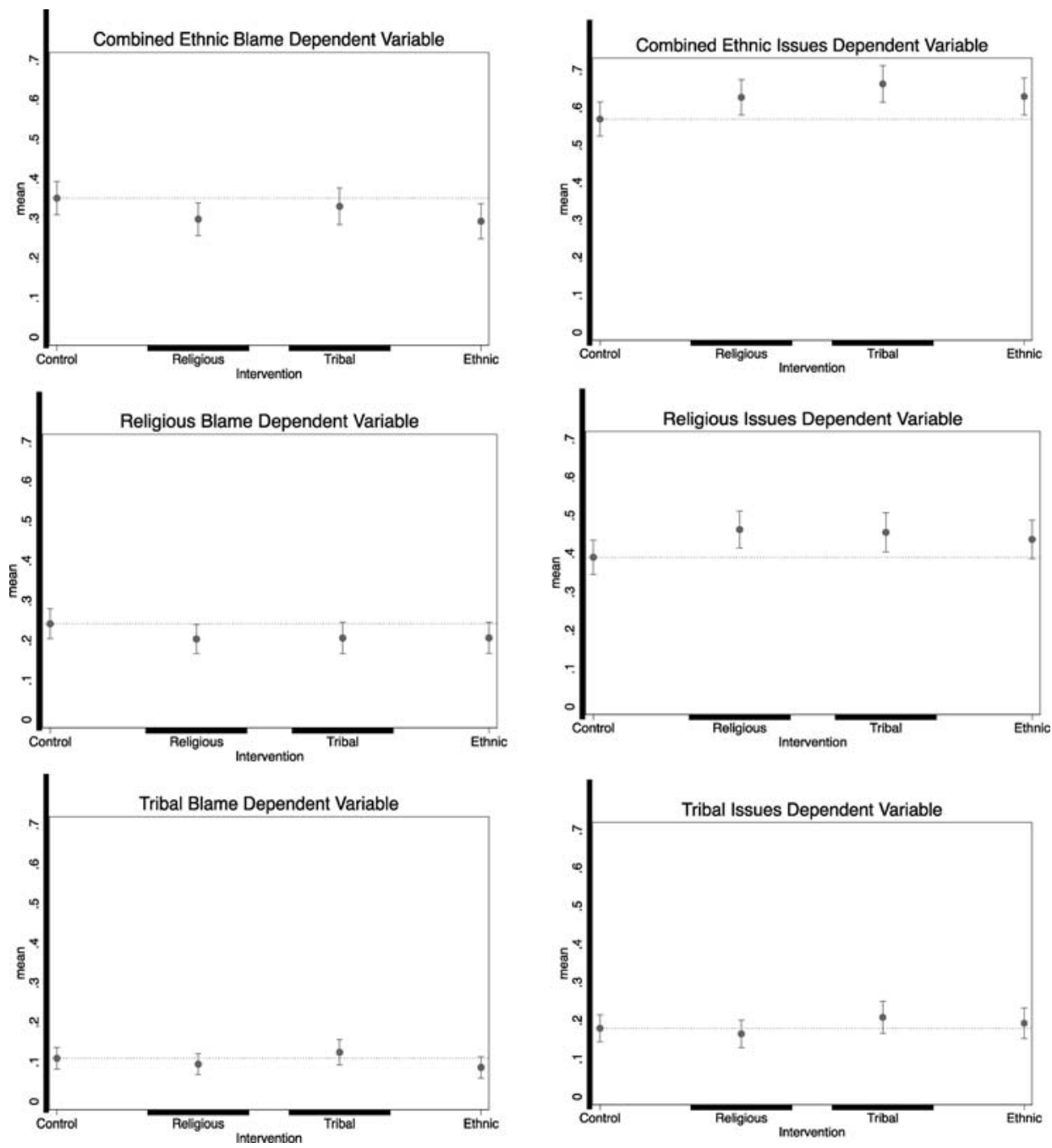

Figure 1. Comparison of proportions and confidence intervals of dependent variables. Each plot contains the proportion of responses for a dependent variable across the control and three treatments, with the left column of plots illustrating the three 'blame' dependent variables, and the right column of plots representing the 'issue' dependent variables

while incidents with 26-50 deaths and 51-100 deaths account for around 10\% and 7\% of total lethal incidents, respectively. Jos has experienced communal ethnic violence at all levels over the past two decades, with some small-scale incidents involving a few deaths, and other clashes, such as those in 2008 and 2010, leading to as many as 7001,000 deaths (Krause, 2011). Although Jos and the surrounding area is commonly affected by incidents involving a handful of deaths, subjects might question why they had not heard of a case of violence involving hundreds of dead. An incident in the range of 50 deaths qualifies as a significant incident of communal violence, given that smaller incidents and even clashes in which one person is killed can bring soldiers out to the streets, shut 
down an entire neighbourhood, and/or lead to a curfew on the entire city. In short, balancing these considerations, we opted to reference approximately 50 deaths to emphasize the significance of the incident and elicit subjects' true perceptions and attitudes as they reflect on similar events in Jos while maintaining the plausibility of the article. ${ }^{7}$

Two questions in the survey experiment are related to the hypotheses. The first question asks 'Who do you think is most responsible for causing this type of violence when it has occurred in Jos?' The possible answers include religious groups, tribal groups, politicians, youths, and cults. From this question, we derive three dependent variables to conform to our hypotheses. A binary 'religious' variable is coded ' 1 ' if a respondent indicates religious groups are to blame, and ' 0 ' otherwise. A binary 'tribal' variable is coded ' 1 ' if a respondent indicates tribal groups are responsible, and ' 0 ' otherwise. The final 'ethnic' variable is coded as ' 1 ' for responses indicating either religious or tribal groups are responsible, and ' 0 ' otherwise. By coding a series of binary variables, we can test Hypotheses 1a, $1 \mathrm{~b}$, and $1 \mathrm{c}$ with a dependent variable representing ethnic groups (Hypothesis 1a), religious groups (Hypothesis 1b), and tribal groups (Hypothesis 1c).

The second survey question focuses on the issues involved in conflict: 'Which of the following issues do you think is the biggest MAJOR CAUSE of the type of violence described in the article when it occurs in Jos?' and the possible responses include religious and tribal issues as well as other issues unrelated to ethnicity. Similar to above, three binary variables are created: (1) a combined 'ethnic' issues variable coded ' 1 ' if a respondent indicates either a religious or tribal issue as the cause, (2) a religious variable coded ' 1 ' if a religious issue is indicated, and (3) a tribal variable coded ' 1 ' if a tribal issue is indicated.

\section{Results}

The left column of Figure 1 illustrates the effects of the three treatments on the likelihood that individuals blame combined ethic, religious, or tribal groups. ${ }^{8}$ The framing of the conflict in the treatment as either tribal or religious has little effect on whether or not respondents blame religious or tribal groups for the conflict. ${ }^{9}$ Indeed, in many cases the prompts appear to have a negative effect on whether respondents blame these groups. These results are supported by logistic regression analysis (see Table 1), which indicates no statistically significant direct relationships between any of the treatments and blame towards religious or tribal groups. The logistic regression does indicate a statistically significant relationship between the religious and combined ethnic treatment and the combined 'ethnic' dependent variable, but the relationships are opposite of the hypothesized relationship. Hypotheses $1 \mathrm{a}, 1 \mathrm{~b}$, and $1 \mathrm{c}$ are, therefore, not supported by the evidence.

These results do not necessarily suggest that religious and tribal identities are innate or unchanging, as arguments regarding the malleability of various ethnic identities typically rely on attempts to exploit ethnic cleavages for political gain (Chandra, 2006, 2012; Chandra \& Wilkinson, 2008; Cordell \& Wolff, 2010, p. 15; Horowitz, 2001, pp. 5254), whereas the treatments in this study were framed as impartial news or information. The above results may mean that individuals are relatively set in terms of the groups they feel are responsible for local communal conflict, but it may also mean that the treatments, as clear as they are in terms of tribal or religious responsibility, are not 'strong' enough to alter these predispositions.

A third possibility is that the framing of events as either religious or tribal may have differing influences on individual perceptions of the underlying issues driving conflict, as we 
Table 1. Logistic regressions of the 'blame' dependent variable: first column reports the binary variable representing the combined ethnic responses (' 1 ' is local religious or tribal group), the next column reports the binary religious response variable (' 1 ' is local religious groups only), and the final column reports the binary tribal response variable (' 1 ' is local tribal groups only)

\begin{tabular}{lccc}
\hline & 'Ethnic' DV & 'Religious' DV & 'Tribal' DV \\
\hline Religious treatment & $-0.24^{*}$ & -0.22 & -0.16 \\
& $(0.14)$ & $(0.16)$ & $(0.21)$ \\
Tribal treatment & -0.09 & -0.21 & 0.15 \\
& $(0.14)$ & $(0.16)$ & $(0.21)$ \\
Ethnic treatment & $-0.27^{*}$ & -0.20 & -0.26 \\
& $(0.14)$ & $(0.16)$ & $-2.10^{* *}$ \\
Constant & $-0.61^{* *}$ & $-1.14^{* *}$ & $(0.14)$ \\
& $(0.09)$ & $(0.10)$ & 1,769 \\
$n$ & 1,769 & 1,769 & 0.29 \\
$p>\chi^{2}$ & 0.18 & 0.42 & -586.48 \\
Log Likelihood & -1105.70 & -921.52 &
\end{tabular}

Note: Parentheses contain standard errors, and $*=p<0.1,{ }^{* *}=p<0.05$ (two-tailed test).

in fact find. For instance, all of the treatments appear to increase the proportion of respondents that indicate religious issues as the cause of the conflict (illustrated in the second plot in the right column of Figure 1), with proportions tests confirming these differences are statistically significant in one-tailed tests at the $p<0.1$ level. ${ }^{10}$

Furthermore, logistic regression analysis (see Table 2) indicates that the religious and tribal treatments seem to increase the proportion of respondents indicating an 'ethnic' or religious cause of the conflict (see first column of Table 2). Comparing the religious and tribal issues (second and third column), however, indicates the treatments have no discernable influence on the likelihood respondents indicate tribal issues as the cause, even

Table 2. Logistic regressions of 'issues' response variable: first column reports the combined ethnic response as the dependent variable (' 1 ' coded for either religious or tribal issue response), second column reports the religious response as the dependent variable (' 1 ' coded for religious issue response only), and final column reports the tribal response as the dependent variable (' 1 ' coded for tribal issue response only)

\begin{tabular}{lccc}
\hline & 'Ethnic' DV & 'Religious' DV & 'Tribal' DV \\
\hline Religious treatment & $0.24^{*}$ & $0.30^{* *}$ & -0.10 \\
& $(0.14)$ & $(0.14)$ & $(0.18)$ \\
Tribal treatment & $0.40^{* *}$ & $0.27^{*}$ & 0.18 \\
& $(0.15)$ & $(0.14)$ & $(0.18)$ \\
Ethnic treatment & $0.25^{*}$ & 0.19 & 0.09 \\
& $(0.14)$ & $(0.14)$ & $-1.52^{* *}$ \\
Constant & $0.28^{* *}$ & $-0.45^{* *}$ & $(0.12)$ \\
& $(0.10)$ & $(0.10)$ & 1,585 \\
$n$ & 1,585 & 1,585 & 0.46 \\
$p>\chi^{2}$ & 0.05 & 0.13 & -758.89 \\
Log Likelihood & -1048.39 & -1082.27 &
\end{tabular}

Note: Parentheses contain standard errors, and $*=p<0.1, * *=p<0.05$ (two-tailed test). 
when the treatment clearly states that the conflict was tribal in nature. On the other hand, both the religious and tribal treatments are associated with an increase in identifying religious issues as the cause of conflict. Hypothesis $2 \mathrm{a}$ and $2 \mathrm{~b}$, therefore receive some support from these results, but the tribal issue hypothesis (Hypothesis 2c) does not.

The implication here is that research that aggregates dimensions of identity into a single 'ethnic' measure potentially mis-specifies identity and overlooks the explanatory potential of different ethnic dimensions. In Jos, for example, we find that the religious dimension is more salient than tribal identity in explaining how individuals view local conflict, but there are many potential cleavages among religious groups as well. To illustrate this, we disaggregate Muslim and Christian subsamples, and find that Christians and Muslims perceive causes of conflict quite differently (see Figures 4 and 5 in the appendix). Although neither religious group is willing to blame religious groups (left columns of Figures 4 and 5 in the appendix), Christians are more likely to identify religious issues as the underlying cause of the conflict, regardless of the treatment that is presented, while Muslims are not (right columns of Figures 4 and 5 in the appendix). Table 3 summarizes a logistic regression analysis that supports this finding for the religious issues dependent variable.

The status of groups may colour interpretations of communal violence with potentially important short- and long-term consequences for peacebuilding attempts. For example, Muslims may be more directly affected by the debates about which tribal groups are 'indigenous,' as this issue disproportionately affects Hausa-Fulani populations in the region (see Human Rights Watch, 2006; Kwaja, 2011). Since Jos was established as a tin mining town during colonial rule and attracted migrants from different parts of Nigeria, including many Hausa from northern Nigeria, the designation of the Hausa population as non-indigenous has long been hotly contested, with both sides asserting claims to original settlement and therefore 'ownership' of Jos (Best, 2008; Kwaja, 2011; Milligan, 2013). This cleavage is reinforced by the vague treatment of indigenous identity in Nigeria's constitution and by contestation at the local government level over who should be counted as an indigene (Higazi, 2011, p. 10). Jos' more restrictive recognition of indigeneity and the political use of indigeneity certificates has contributed to the city's tensions, as non-indigenes are disadvantaged in their access to employment, university education and

Table 3. Logistic regressions of 'religious issues' response variable: first column reports those that identifies as Christians, while the second column reports those that identified as Muslim

\begin{tabular}{lcc}
\hline & 'Religious Issues': Christians & 'Religious Issues': Muslims \\
\hline Religious treatment & $0.38^{* *}$ & 0.005 \\
& $(0.17)$ & $(0.30)$ \\
Tribal treatment & $0.59^{* *}$ & -0.32 \\
& $(0.18)$ & $(0.32)$ \\
Ethnic treatment & $0.38^{* *}$ & -0.18 \\
& $(0.17)$ & $(0.31)$ \\
Constant & -0.12 & $-1.29^{* *}$ \\
& $(0.11)$ & $(0.21)$ \\
$n$ & 1,071 & 508 \\
$p>\chi^{2}$ & 0.006 & 0.698 \\
Log Likelihood & -731.428 & -251.254 \\
\hline
\end{tabular}

Note: Parentheses contain standard errors, and $*=p<0.1, * *=p<0.05$ (two-tailed test). 
scholarships, land, the civil service, and political representation (Human Rights Watch, 2006; Krause, 2011; Kwaja, 2011; Madueke \& Vermeulen, 2018, p. 45; Ostien, 2009). ${ }^{11}$

Christians, on the other hand, are more likely to view these conflicts as motivated by underlying religious issues. In Plateau state and more broadly, Christians suspect Muslim northerners of a nefarious religio-political agenda to 'conquer' Nigeria, and Muslims are suspicious of the rapid growth of an evangelistic and highly decentralized Pentecostal-charismatic Christianity (Marshall, 2009, p. 229; Paden, 2012; Vinson, 2017, p. 189). While the conflict has various dimensions, '[r]eligious identities have become strongly polarized and one-sided conflict narratives internalized' (Krause, 2011, np; see also Segun \& Jegede, 2013). And, as Madueke (2018, p. 452) notes, despite the indigeneity dispute "violence has always taken a religious tone. Individuals are maimed and killed, not because they are indigenes or Hausa, but because they are Christian or Muslim. ${ }^{12}$ Places of worship have also been targeted in the various conflagrations. As a peacebuilder with one local NGO observed, religious leaders on both sides sometimes contribute to perceptions of inter-religious rivalry by bringing 'political issues into preaching and, by implication, preaching hatred, creating fear of the other, and to some extent encouraging people to rise up ... not to accept defeat [from their] opponent. ${ }^{13}$

\section{Implications}

Do these distinctions affect the potential consequences of conflict? This is a complicated question, as the potential consequences are manifold. Perceptions of the causes of conflict could differently shape the views of participants: perceptions of whether conflict is likely to be solved, whether peace building efforts are likely to be effective, what government actors or community leaders should intervene, or what types of solutions should be attempted.

We hope to explore many of these consequences in future work, but it is worth examining some of these consequences here, both to reinforce the importance of these types of studies and to reiterate that our assumptions are not always supported by the evidence. For example, our survey asked whether individuals were hopeful a resolution to conflict could be reached. We expected that if there were differences in blame between tribal or religious groups or tribal or religious issues, that these differences might be associated with optimism or pessimism about the future of violence in the community. If religion tended to be a more salient dimension of ethnic conflict, then perhaps these individuals would be pessimistic about the future of conflict, since religious conflicts are seen as less tractable and face indivisibility hurdles (e.g. Hassner, 2009; Svensson, 2012). This does not appear to be the case. Tables 3 and 4 in the online appendix detail a cross-tabulation (and accompanying $\chi^{2}$ test) with mixed results. There is no clear association between responses regarding religious, tribal, or ethnic issues as the causes of the conflict and hopefulness about conflict resolution.

There is a significant relationship between beliefs about the ethnic nature of conflict and the solutions individuals view as critical to resolving the conflict. Figure 6 in the paper appendix illustrates the distribution of responses to the question 'Of the possible SOLUTIONS for ending this type of violent conflict in Jos, which solution do you think is the most important?' The 'religious solutions' response is the most common when compared to political, economic, tribal, and other solutions. Thus, religious issues are much 
more likely to be seen as the underlying cause of conflict in Jos (see Table 2 in the online appendix), and religious solutions are seen as the most vital for solving the conflict.

In what way might the responses to these two questions be related? Table 4 illustrates that identifying religious issues as important to a conflict is associated with belief that religious solutions are likewise important, rather than the treatments themselves. In other words, perceptions of causes tend to depend on whether a conflict is presented as tribal, religious, or ethnic, while beliefs about solutions tend to depend on whether religious issues are seen as important. This does not preclude a potential indirect effect between priming of conflict and solutions, as results in Table 2 clearly indicate that the treatments influence the responses to the issue question. This once again illustrates the importance of disaggregating ethnic dimensions, as there may be many interesting causal pathways from perceptions of conflict to potential peacebuilding. For example, one potential implication of these findings is that the path to peacebuilding will be difficult if it does not address the way in which identity has been mapped onto or exacerbates grievances. In the peace meeting referenced in the introduction to this article, one participant from an active local NGO argued that peace was impossible between Christians and Muslims in the community because of the religious motivations and ambitions of the religious other (within Jos and writ large). For this participant, as echoed in other fieldwork interviews (see Vinson, 2017), the conflict barriers had taken on a symbolic identity-laden scope, and other political and economic issues were reinterpreted through a religious lens-e.g. viewed as rooted in and mobilized by nefarious religious motives. Consequently, conflict studies must not overlook the various ways in which identity (religious or tribal, in this case) and communal conflict interweave, something that peacebuilding mediation work has long been active in (e.g. Chang \& Peisakhin, 2019; Ditlmann \& Samii, 2016; Scacco \& Warren, 2018; Svensson \& Brouneus, 2013). Our findings suggest the

Table 4. Logistic regression where dependent variable is 1 for religious solutions as the most important, 0 for all other solutions

\begin{tabular}{lcc}
\hline Variable & $\begin{array}{c}\text { Coefficient } \\
\text { (standard errors) }\end{array}$ & $\begin{array}{c}\text { Coefficient } \\
\text { (standard errors) }\end{array}$ \\
\hline Religious treatment & -0.12 & -0.13 \\
& $(0.15)$ & $(0.15)$ \\
Tribal treatment & -0.04 & -0.04 \\
& $(0.15)$ & $(0.16)$ \\
Ethnic treatment & 0.02 & 0.01 \\
& $(0.15)$ & $(0.15)$ \\
Religious issues & $1.51^{* * *}$ & $1.46^{* * *}$ \\
Tribal issues & $(0.12)$ & $(0.32)$ \\
& 0.20 & 0.14 \\
Economic issues & $(0.16)$ & $(0.34)$ \\
Political issues & - & -0.10 \\
& - & $(0.37)$ \\
Constant & - & -0.05 \\
& - & $(0.33)$ \\
\end{tabular}

$n=1,542 ; * p<0.1 ; * * p<0.05 ; * * * p<0.01$. 
importance of understanding how identity becomes a source of cleavage in a community and how the narrative or re-framing of religious (or other) ideas and values can be effectively achieved (e.g. inclusion of religious leaders in dialogue work). Deconstructing stereotypes, prejudice, and identity-based 'othering' may help to defuse the mobilizing capacity of underlying political or economic grievances.

\section{Conclusion}

The dynamics of the Jos, Nigeria conflict allow us to examine whether ethnic identities-in a context of overlapping tribal and religious cleavages-distinctly shape locals' perceptions of the causes of violence. We find that Jos respondents are circumspect or divided when assigning blame to religious or tribal groups, even when exposed to one of the ethnic conflict frames. Although contrary to what we hypothesized, it does comport with discussions with local actors and observations at local peace meetings; individuals seem torn when asked who is to blame for Jos violence, or they accuse every type of actor. However, we find that when violence was framed in religious or tribal terms, this significantly shaped respondents' views of the conflict issues. We find that respondents are more likely to view religious issues at the root of violence, even when prompted to reflect on tribal violence in their community. Additionally, there are clear sub-group differences, with Christians more likely to blame the conflict on religious issues compared to Muslims.

Similar to Canetti et al. (2019), Kolås (2017), and a host of scholars discussed in the literature review, our findings emphasize the broader insights to be gained from moving beyond aggregate studies of ethnic politics or conflict to explore its local or micro dimensions. Despite the 'labels' policy-makers or scholars attach to ethnic conflict, there is nuance embedded in the meaning of those labels to those affected by conflict. Consistent with the social psychology literature, the local constructions of the identity-conflict nexus are significant for inter-group attitudes and conflict.

Although we primarily explore how the different ethnic identities shape conflict attitudes, we also provide preliminary analysis of important implications. We know from scholarship on identity politics that ethnic associations can shape in-group/out-group attitudes such as discrimination, stereotypes, and policy preferences (e.g. Charnysh et al., 2015; Kalin \& Siddiqui, 2020; Robinson, 2016; Selvanathan \& Leidner, 2020; Smirnova \& Lliev, 2017; Tusicisny, 2017). Like Canetti et al. (2019), we argue that the identity frame individuals associate with conflict also has important peacebuilding or conflict resolution implications. First, our finding that respondents do not necessarily blame the relevant ethnic out-group associated with the violence in our prompts can be viewed optimistically. As McDoom (2012, p. 122) discusses, one would expect that as conflict intensifies or persists over time, as it has in Jos, that individuals would more readily assign blame to the opposing group through a process of denigration, 'deindividualization,' and intensified othering of the out-group. In contrast, our analysis suggests that prospects for peacebuilding initiatives may not be futile in their attempts to bring communities together across identity lines, even in a highly divided and segregated conflict community.

Second, however, given that those who received an identity-based conflict prompt in our study are more likely to view the conflict as rooted in religious issues, and view religious solutions as central to conflict resolution, we expect that any peacebuilding success 
in Jos will be dependent on addressing religion as both a contributing factor to the conflict and a necessary solution. These findings push back against work-particularly in the rational choice vein - that tends to treat religion as epiphenomenal and subsidiary to the 'true' political or material/economic factors driving conflict (see Bellin, 2008, pp. 317318 for discussion). Although political and economic factors are associated with conflict causes and issues, ${ }^{14}$ we find that individual's perceptions of how identity maps onto local conflict is powerful in shaping how they view Jos residents' experience of violence. Religious issues are seen as particularly salient dimension of the violence, and religious solutions are viewed as critical for those who think of the violence through an identity lens. Assuming violence is only the result of political and economic issues, although certainly part of the story of Jos' history and grievances, is insufficient for understanding how those who experience the violence actually think about it. Likewise, disaggregating the different dimensions of ethnic identity is critical for understanding how conflict in locations such as Jos begin, recur, and are ultimately addressed peacefully. We agree with Canetti et al.'s (2019, p. 749) conclusion that 'a successful pathway to peace must be a sophisticated one, tailored to address the way in which the core issues are uniquely framed by each party involved.' Attempts to bring communities together are less about the broad strokes of ethnicity and more about the particulars of how people perceive ethnic differences.

\section{Acknowledgements}

The authors wish to thank many individuals and institutions that assisted with this research project. Thank you to Katrina Korb and Danny McCain, professors at the University of Jos for providing vital logistical support as well as local knowledge for the sampling techniques. Additional thanks to Stephen Nemeth for help with the initial stages of the project. Thank you to the Department of Political Science, the Centre for Conflict Management and Peace Studies, and the Dean of the Faculty of Social Sciences at the University of Jos for their institutional support. The following research assistants did invaluable work on this project: Sanni Moses Peter, Abdullahi Yusuf, Abdullahi Salmanu, Abubakar Nabeel Abdulkareem, Bot Polycarp Moses, Bulus Jonathan Charles, Chidozie Diamond Anyalewechi, Francis Emmanuel Tsaku, Fariatu Yahuza Ahmad, Ibrahim Musa Nuhu, Salihu Madinatu, Mafeng David Bot, Temitope Olamide Osoba, Omeka Matthew, and Ruqayya Sulaiman Nayaya.

\section{Funding}

This work was supported by the Peace Research Grant Program of the International Peace Research Association Foundation.

\section{Supplemental Data}

Supplemental data for this article can be accessed at https://doi.org/10.1080/17449057. 2020.1863019. 


\title{
Data Availability Statement
}

\author{
Data available through the Oklahoma State institutional repository (SHAREOK) at https:// \\ doi.org/10.22488/okstate.20.000004.
}

\section{Notes}

1. Note that references to 'tribe' or 'tribal identity' are not intended to be derogatory or imply something backward about African or Nigerian society. While some scholars prefer to use the 'ethnic' or 'ethnolinguistic' descriptors, we use the term tribe or ethno-tribal for two important reasons. First, the designation 'ethnic' is commonly used as an umbrella category for various ethnic identities - e.g. language, caste, race, tribe, and religion (Chandra, 2012, p. 9; Chandra \& Wilkinson, 2008, p. 519; Horowitz, 1985, p. 53). This can be confusing when talking about two categories of ethnicity. Second, and more importantly, Nigerians themselves refer to their ethno-linguistic or kinship identity as their tribal affiliation, as is common throughout Africa (Miguel, 2004, p. 329; Posner, 2007, pp. 1303-1304).

2. Note that we use communal and ethnic violence or riots interchangeably, consistent with work by other scholars (e.g. Horowitz, 2001, p. 1).

3. Initially, we collected 2,209 surveys. We deleted 17 surveys that were flagged by research assistants as problematic (e.g. a case where the randomization protocol for household participants failed), and there were 139 incomplete surveys (i.e. no ending time stamp was recorded). The larger issue was that despite daily efforts to monitor research assistants, we discovered a cluster of surveys that took an incredibly short amount of time, and were tied to a single research assistant. We discovered that this research assistant had fabricated surveys, and as a precaution, all 284 surveys in which this individual was involved were removed from the sample. A data appendix containing more information can be found at http:// peterrudloff.net/files/jos_data_appendix.pdf.

4. There may be political or logistical reasons for placing polling stations other than population density. Political leaders might place polling stations in locations that are more easily defended from attack. A political regime, to ensure that a group is underrepresented in an election, might provide relatively few polling places in certain ethnic areas. This introduces potential bias along ethnic dimensions.

5. We further discuss the ethical challenges of carrying out this type of research in an area that has experienced communal conflict in a subsequent methods paper (Rudloff \& Vinson, in press).

6. The full set of questions are available from the authors.

7. See Rudloff and Vinson (in press) for the discussion of the ethical considerations and procedures adopted to design this project in a manner sensitive to the Jos environment and participants' experiences of communal violence.

8. Tables 1 and 2 in the paper appendix contain full cross-tabulations of the treatments and key issue and group dependent variables. A significant number of respondents identified political and economic factors as important, other in terms of blame and the issues causing the conflict. This is unsurprising, given that the intersection of economic and political factors with the identity-based factors we are interested in for this paper (e.g. see Vinson \& Rudloff, in press). Although the purpose of this paper is on the importance of disaggregating identity dimensions of conflict, it is important to note that this does not preclude the importance of material factors.

9. Additionally, across all four treatments, a sizeable portion of respondents (between 22 and 29 percent) blame 'terrorists' for the violence in Jos (see Table 1 in the appendix), suggesting that the increase in Boko Haram violence in northern Nigeria since 2011 is influencing how individuals interpret communal violence.

10. For the religious treatment, proportion(religious treatment) $>$ proportion (control) leads to $p=0.0157$; for tribal treatment, proportion(tribal treatment) $>$ proportion(control) leads to $p=0.0305$; and for combined ethnic treatment, proportion(ethnic treatment) $>$ proportion(control) leads to $p=0.0858$.

11. The creation of Jos North from the larger Jos Local Government Area in 1991 exacerbated the politics of indigeneity and Jos ownership, as indigenous groups perceived this move by the national government as effectively ceding to the Hausa population control of the main Jos metropolis, the majority in this area (Ostien, 2009, pp. 8-9; Kwaja, 2011; Krause, 2011; Vinson, 2017, p. 212ff). There have long been calls for the federal government to address the constitution's vague definition of indigeneity, as it allows state and local governments to determine at their own whim or for political interests who 
'legitimately' deserves certificates of indigeneity (e.g. Human Rights Watch, 2006; Kwaja, 2011; Osaretin \& Akov, 2013).

12. Human Rights Watch (2001) discusses how religion was used as a litmus test in the Jos 2001 conflagration.

13. Anonymous, interview by Laura Thaut Vinson, March 30, 2011, Jos, Nigeria.

14. Indeed, Table 1 in the paper appendix indicates that political actors are seen as more commonly to blame than religious or tribal groups, and Table 2 in the paper appendix indicates that political issues are seen as the second most important cause behind religious issues.

\section{ORCID}

Laura Thaut Vinson (D) http://orcid.org/0000-0002-8276-9248

Peter Rudloff (iD http://orcid.org/0000-0002-5687-7069

\section{References}

Allport, G. W. (1954). The nature of prejudice. Addison-Wesley.

Aroopala, C. (2012). Mobilizing collective identity: Frames \& rational individuals. Political Behavior, 34(2), 193-224. https://doi.org/10.1007/s11109-010-9155-4

Basedau, M., Strüver, G., Vüllers, J., \& Wegenast, T. (2011). Do religious factors impact armed conflict? Empirical evidence from sub-Saharan Africa (GIGA Working Papers, No. 168). German Institute of Global and Area Studies (GIGA).

Bellin, E. (2008). Faith in politics: New trends in the study of religion and politics. World Politics, 60, 315-347. https://doi.org/10.1353/wp.0.0007

Best, S. G. (Ed.). (2008). Causes and effects of conflicts in the Southern Zone of Plateau State, Nigeria. University of Jos, Nigeria: Centre for Conflict Management and Peace Studies.

Brass, P. R. (1997). Theft of an idol: Text and context in the representation of collective violence. Princeton University Press.

Brewer, M. B. (1999). The psychology of prejudice: Ingroup love and outgroup hate? Journal of Social Issues, 55 (3), 429-444. https://doi.org/10.1111/0022-4537.00126

Brubaker, R. (2015). Grounds for difference. Harvard University Press.

Brubaker, R., \& Laitin, D. D. (1998). Ethnic and nationalist violence. Annual Review of Sociology, 24(1), 423452. https://doi.org/10.1146/annurev.soc.24.1.423

Bunte, J., \& Vinson, L. (2016). Local power-sharing institutions and interreligious violence in Nigeria. Journal of Peace Research, 53(1), 49-65. https://doi.org/10.1177/0022343315614999

Campbell, J., \& Page, M. (2018). Nigeria: What everyone needs to know. Oxford University Press.

Canetti, D., Khatib, I., Rubin, A., \& Wayne, D. (2019). Framing and fighting: The impact of conflict frames on political attitudes. Journal of Peace Research, 56(6), 737-752. https://doi.org/10.1177/0022343319826324

Canetti-Nisim, D., Ariely, G., \& Halperin, E. (2008). Life, pocketbook, or culture: The role of perceived security threats in promoting exclusionist political attitudes toward minorities in Israel. Political Research Quarterly, 61(1), 90-103. https://doi.org/10.1177/1065912907307289

Chandra, K. (2006). What is ethnic identity and does it matter? Annual Review of Political Science, 9(1), 397424. https://doi.org/10.1146/annurev.polisci.9.062404.170715

Chandra, K. (Ed.). (2012). Constructivist theories of ethnic politics. Oxford University Press.

Chandra, K., \& Wilkinson, S. (2008). Measuring the effect of 'ethnicity'. Comparative Political Studies, 41(4-5), 515-563. https://doi.org/10.1177/0010414007313240

Chang, H. I., \& Peisakhin, L. (2019). Building cooperation among groups in conflict: An experiment on intersectarian cooperation in Lebanon. American Journal of Political Science, 63(1), 146-162. https://doi.org/10. 1111/ajps. 12397

Charnysh, V., Lucas, C., \& Singh, P. (2015). The ties that bind: National identity salience and pro-social behavior toward the ethnic other. Comparative Political Studies, 48(3), 267-300. https://doi.org/10.1177/ 0010414014543103

Cordell, K., \& Wolff, S. (2010). Ethnic conflict: Causes, consequences, responses. Polity Press. 


\section{L. Thaut Vinson and P. Rudloff}

Dessel, A., \& Rogge, M. (2008). Evaluation of intergroup dialogue: A review of the empirical literature. Conflict Resolution Quarterly, 26(2), 199-238. https://doi.org/10.1002/crq.230

Ditlmann, R. K., \& Samii, C. (2016). Can intergroup contact affect ingroup dynamics? Insights from a field study with Jewish and Arab-Palestinian youth in Israel. Peace and Conflict: Journal of Peace Psychology, 22(4), 380-392. https://doi.org/10.1037/pac0000217

Dowd, R. (2014). Religious diversity and violent conflict: Lessons from Nigeria. Fletcher Forum of World Affairs, 38, 153-168. https://static1.squarespace.com/static/579fc2ad725e253a86230610/t/ 57ec7841be6594808a4543f7/1475115074402/38-1_Dowd1.pdf

Falola, T. (1998). Violence in Nigeria: The crisis of religious politics and secular ideologies. University of Rochester Press.

Finkel, S., Horowitz, J., \& Rojo-Mendoza, R. T. (2012). Civic education and democratic dacksliding in the wake of Kenya's post-2007 election violence. Journal of Politics, 74(1), 52-65. https://doi.org/10.1017/ S0022381611001162

Fjelde, H., \& Østby, G. (2014). Socioeconomic inequality and communal conflict: A disaggregated analysis of sub-Saharan Africa, 1990-2008. International Interactions, 40(5), 737-762. https://doi.org/10.1080/ 03050629.2014.917373

Flesken, A. (2014). On the link between ethnic politics and identification: Lessons from Bolivia. Ethnopolitics, 13 (2), 159-180. https://doi.org/10.1080/17449057.2013.825436

Gagnon Jr, V. P. (1994). Ethnic nationalism and international conflict: The case of Serbia. International Security, 19(3), 130-166. https://doi.org/10.2307/2539081

Gohdes, A. R. (2017). Bringing perpetrator and victim identities into empirical ethnic conflict research. Ethnopolitics, 16(1), 28-33. https://doi.org/10.1080/17449057.2016.1235344

Google. (2016). Google Earth Pro. https://www.google.com/earth/

Green, D. P., \& Seher, R. L. (2003). What role does prejudice play in ethnic conflict. Annual Review of Political Science, 6(1), 509-531. https://doi.org/10.1146/annurev.polisci.6.121901.085642

Gurr, T. R. (2000). Peoples versus states: Minorities at risk in the new century. US Institute of Peace Press.

Gurr, T. R. (2017). Observations on the study of ethnic conflict. Ethnopolitics, 16(1), 34-40. https://doi.org/10. $1080 / 17449057.2016 .1235345$

Gurses, M. (2015). Is Islam a cure for ethnic conflict? Evidence from Turkey. Politics and Religion, 8(1), 135154. https://doi.org/10.1017/S1755048315000024

Gurses, M. (2018). Anatomy of a civil war: Sociopolitical impacts of Kurdish conflict in Turkey. University of Michigan Press.

Hale, H. (2017). Focus on the fundamentals: Reflections on the state of ethnic conflict studies. Ethnopolitics, 16(1), 41-47. https://doi.org/10.1080/17449057.2016.1235346

Hasenclever, A., \& Rittberger, V. (2000). Does religion make a difference? Theoretical approaches to the impact of faith on political conflict. Journal of International Studies, 29, 641-674. https://doi.org/10.1177/ 03058298000290031401

Hassner, R. (2009). War on sacred grounds. Cornell University Press.

Higazi, A. (2011). The Jos crisis: A recurrent Nigerian tragedy (Discussion Paper no. 2). Friedrich-Ebert-Stiftung (FES) Nigeria, Abuja. http://library.fes.de/pdf-files/bueros/nigeria/07812.pdf

Horowitz, D. (1985). Ethnic groups in conflict. University of California Press.

Horowitz, D. (2001). The deadly ethnic riot. University of California Press.

Human Rights Watch. (2001, December 18). Jos: A city torn apart. https://www.hrw.org/report/2001/12/18/jos/ city-torn-apart

Human Rights Watch. (2006, April 25). Nigeria: Indigeneity policies marginalize millions. https://www.hrw.org/ news/2006/04/25/nigeria-indigeneity-policies-marginalize-millions\#

Human Rights Watch. (2011, January 27). Nigeria: A new wave of violence leaves 200 dead. https://www.hrw. org/news/2011/01/27/nigeria-new-wave-violence-leaves-200-dead\#

International Crisis Group. (2018, July 26). Stopping Nigeria's spiraling farmer-herder violence (Report No. 262), https://www.crisisgroup.org/africa/west-africa/nigeria/262-stopping-nigerias-spiralling-farmerherder-violence

Kalin, M., \& Siddiqui, N. (2020). National identity, religious tolerance, and group conflict: Insights from a survey experiment in Pakistan. Conflict Management and Peace Science, 37(1), 58-82. https://doi.org/10.1177/ 0738894217724568

Kasara, K. (2013). Separate and suspicious: Local social and political context and ethnic tolerance in Kenya. Journal of Politics, 75(4), 921-936. https://doi.org/10.1017/S0022381613000777 
Kaufman, S. (2001). Modern hatreds: The symbolic politics of ethnic war. Cornell University Press.

Kolås, Å. (2017). Framing the tribal: Ethnic violence in northeast India. Asian Ethnicity, 18(1), 22-37. https://doi. org/10.1080/14631369.2015.1062050

Krause, J. (2011). A deadly cycle: Ethno-religious conflict in Jos, Plateau State, Nigeria (Working Paper). Geneva Declaration Secretariat. http://www.genevadeclaration.org/fileadmin/docs/regional-publications/ GD-WP-Jos-deadly-cycle.pdf

Krause, J. (2017). Non-violence and civilian agency in communal war: Evidence from Jos, Nigeria. African Affairs, 116, 261-283. https://doi.org/10.1093/afraf/adw068

Krause, J. (2019). Gender dimensions of (non) violence in communal conflict: The case of Jos, Nigeria. Comparative Political Studies (published online March 4, 2019). https://doi.org/10.1177/0010414019830722

Kwaja, C. (2011). Nigeria's pernicious drivers of ethno-religious conflict. Africa Center for Strategic Studies.

Laitin, D. (1986). Hegemony and culture: Politics and religious change among the Yoruba. University of Chicago Press.

Madueke, K. L. (2018). Routing ethnic violence in a divided city: Walking in the footsteps of armed mobs in Jos, Nigeria. Journal of Modern African Studies, 56(3), 443-470. https://doi.org/10.1017/S0022278X18000320

Madueke, K. L., \& Vermeulen, F. F. (2018). Frontiers of ethnic brutality in an African city: Explaining the spread and recurrence of violent conflict in Jos, Nigeria. Africa Spectrum, 53(2), 37-63. https://doi.org/10.1177/ 000203971805300203

Marshall, R. (2009). Political spiritualities: The Pentecostal revolution in Nigeria. University of Chicago Press.

Mayowa, O. A. (2001). State and ethno-communal violence in Nigeria: The case of Ife-Modakeke. Africa Development/Afrique et Développement, 26, 195-223. https://doi.org/10.4314/ad.v26i1.22136

McCauley, J. F. (2017). Disaggregating identities to study ethnic conflict. Ethnopolitics, 16(1), 12-20. https://doi. org/10.1080/17449057.2016.1235348

McDoom, O. S. (2012). The psychology of threat in intergroup conflict: Emotions, rationality, and opportunity in the Rwandan genocide. International Security, 37(2), 119-155. https://doi.org/10.1162/ISEC_a_00100

Miguel, E. (2004). Tribe or nation? Nation building and public goods in Kenya versusTanzania. World Politics, 56, 327-362. https://doi.org/10.1017/S0043887100004330

Milligan, M. (2013). Fighting for the right to exist: Institutions, identity, \& conflict in Jos, Nigeria. Comparative Politics, 45(3), 313-334. https://doi.org/10.5129/001041512X13815255434933

Nova Research Company. (2016). Questionnaire development system, version 3.0. http://www.novaresearch. com/Products/qds/index.cfm

Osaretin, I., \& Akov, E. (2013). Ethno-religious conflict and peace building in Nigeria: The case of Jos, Plateau State. Academic Journal of Interdisciplinary Studies, 2, 341-360. https://doi.org/10.5901/ajis.2013. v2n1p349

Ostien, P. (2009). Jonah Jang and the Jasawa: Ethno-religious conflict in Jos, Nigeria. Muslim-Christian Relations in Africa. Available at SSRN: https://ssrn.com/abstract=1456372

Paden, J. N. (2012). Postelection conflict management in Nigeria: The challenges of national unity. George Mason University.

Pettigrew, T. F., \& Tropp, L. R. (2006). A meta-analytic test of intergroup contact theory. Journal of Personality and Social Psychology, 90(5), 751-783. https://doi.org/10.1037/0022-3514.90.5.751

Pierskalla, J. H., \& Sacks, A. (2017). Unpacking the effect of decentralized governance on routine violence: Lessons from Indonesia. World Development, 90, 213-228. https://doi.org/10.1016/j.worlddev.2016.09.008

Posner, D. N. (2004). The political salience of cultural differences: Why Chewas and Tumbukas are allies in Zambia and adversaries in Malawi. American Political Science Review, 98(4), 529-545. https://doi.org/ 10.1017/S0003055404041334

Posner, D. N. (2007). Regime change and ethnic cleavages in Africa. Comparative PoliticalStudies, 40(11), 1302-1327. https://doi.org/10.1177/0010414006291832

QGIS Development Team. (2016). QGIS Geographic Information System. Open Source Geospatial Foundation Project. http://www.qgis.org/

Robinson, A. L. (2016). Nationalism and ethnic-based trust: Evidence from an African border region. Comparative Political Studies, 49(14), 1819-1854. https://doi.org/10.1177/0010414016628269

Ross, M. H. (2009). Culture and belonging in divided societies: Contestation and symbolic landscapes. University of Pennsylvania Press.

Rudloff, P., \& Vinson, L. T. (in press). Surveys in communities divided by ethnicity and conflict: Challenges, possible solutions, and lessons learned from a survey in Jos, Nigeria. Sociological Methods \& Research. 


\section{L. Thaut Vinson and P. Rudloff}

Samii, C. (2013). Perils or promise of ethnic integration? Evidence from a hard case in Burundi. American Political Science Review, 107(3), 558-573. https://doi.org/10.1017/S0003055413000282

Scacco, A. (2010). Who riots? Explaining individual participation in ethnic violence $[\mathrm{PhD}$ dissertation, Columbia University]. http://citeseerx.ist.psu.edu/viewdoc/download?doi=10.1.1.615.3726\&rep=rep1\&type=pdf

Scacco, A., \& Warren, S. S. (2018). Can social contact reduce prejudice and discrimination? Evidence from a field experiment in Nigeria. American Political Science Review, 112(3), 654-677. https://doi.org/10.1017/ S0003055418000151

Segun, J., \& Jegede, A. E. (2013). Ethnicisation of violent conflicts in Jos? Global Journal of Human Social Science, 13, 1-7. http://eprints.covenantuniversity.edu.ng/id/eprint/7524

Selvanathan, H. P., \& Leidner, B. (2020). Modes of ingroup identification and notions of justice provide distinct pathways to normative and nonnormative collective action in the Israeli-Palestinian conflict. Journal of Conflict Resolution, 64(9), 1-35. https://doi.org/10.1177/0022002720907660

Smirnova, A., \& Lliev, R. (2017). Political and linguistic identities in an ethnic conflict. Journal of Language and Social Psychology, 36(2), 211-225. https://doi.org/10.1177/0261927X16643559

Stewart, F. (2008). Horizontal inequalities and conflict: Understanding group violence in multiethnic societies. Palgrave Macmillan.

Svensson, I. (2012). Ending holy wars: Religion and conflict resolution in civil wars. University of Queensland Press.

Svensson, I., \& Brouneus, K. (2013). Dialogue and interethnic trust: A randomized field trial of 'sustained dialogue' in Ethiopia. Journal of Peace Research, 50(5), 563-575. https://doi.org/10.1177/0022343313492989

Tajfel, H., \& Turner, J. C. (2004). An integrative theory of intergroup conflict. In M. J. Hatch \& M. Schultz (Eds.), Organizational identity: A reader (pp. 56-65). Oxford University Press.

Tusicisny, A. (2017). Reciprocity and discrimination: An experiment of Hindu-Muslim cooperation in Indian slums. Political Psychology, 38(3), 409-426. https://doi.org/10.1111/pops.12340

Varshney, A. (2001). Ethnic conflict and civil society: India and beyond. World Politics, 53(3), 363-398. https:// doi.org/10.1353/wp.2001.0012

Varshney, A. (2003). Nationalism, ethnic conflict, and rationality. Perspectives on Politics, 1(1), 85-99. https:// doi.org/10.1017/S1537592703000069

Vinson, L. T. (2017). Religion, violence, and local power-sharing in Nigeria. Cambridge University Press.

Vinson, L. T. (2020). Disaggregating ethnicity and conflict patterns: Evidence from religious and tribal violence in Nigeria. Ethnopolitics, 19(1), 19-44. https://doi.org/10.1080/17449057.2018.1536376

Vinson, L. T., \& Rudloff, P. (in press). Perceptions of local vs. National factors in religious and tribal conflict: Evidence from a survey in Jos, Nigeria. Politics and Religion.

Wimmer, A. (2008). The making and unmaking of ethnic boundaries: A multilevel process theory. American Journal of Sociology, 113(4), 970-1022. https://doi.org/10.1086/522803 